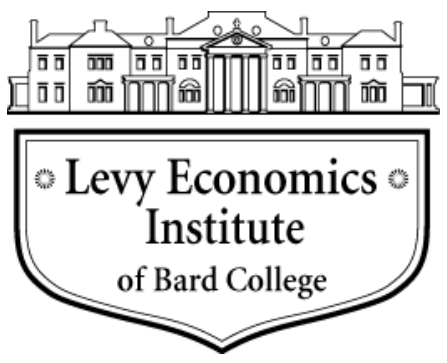

Working Paper No. 976

\title{
The Palestinian Labor Market over the Last Three Decades
}

by

\author{
Sameh Hallaq \\ Levy Institute and \\ Al-Quds Bard College
}

November 2020

The Levy Economics Institute Working Paper Collection presents research in progress by Levy Institute scholars and conference participants. The purpose of the series is to disseminate ideas to and elicit comments from academics and professionals.

Levy Economics Institute of Bard College, founded in 1986, is a nonprofit, nonpartisan, independently funded research organization devoted to public service. Through scholarship and economic research it generates viable, effective public policy responses to important economic problems that profoundly affect the quality of life in the United States and abroad.

Levy Economics Institute

P.O. Box 5000

Annandale-on-Hudson, NY 12504-5000

http://www.levyinstitute.org

Copyright (C) Levy Economics Institute 2020 All rights reserved

ISSN 1547-366X 


\begin{abstract}
This paper consists of three economic literature review essays that survey the Palestinian labor market during the last three decades. The first essay examines the economic return to schooling since 1981 until the recent period, taking into consideration the major shocks that the Palestinian economy experienced, such as the First and Second Palestinian Intifadas (1987-93 and 2000-5), respectively, and the establishment of the Palestinian National Authority in 1993. A special focus is laid on overcoming the potential endogeneity arising from the schooling coefficient. The second essay discusses the economic costs of several conflict measures (e.g., time and geographical variation in fatalities and other conflict incidents, days under curfews, checkpoints, movement restrictions, and substitution of foreigner workers for Palestinian labor) on the labor market and human capital. Earnings and unemployment are the main labor market indicators, while the human capital impact was assessed by educational attainment. The third essay sheds light on the wage differential in the Palestinian labor market due to geographical and employment sector factors.
\end{abstract}

KEYWORDS: Returns to Schooling; Israeli-Palestinian Conflict; Wage Differential

JEL CLASSIFICATIONS: E24; J31; J24; J40; J61 


\section{THE ECONOMIC RETURNS TO SCHOOLING IN PALESTINE}

The returns to education are an important matter for all policymakers, since they have a direct impact at both the individual and social level. The individual wage (unemployment) increases (decreases) with schooling. Education can secure better job opportunities and increase knowledge and skills. At the national level, education plays a significant role in determining long-run GDP. Also, human capital attainment affects aggregate output. School choice is considered an investment decision with opportunity costs. These costs include the total expenditure on education as well as income that could be generated if a person is working rather than attending school. Economists such as Schultz (1961), Becker (1964), and Mincer (1974) developed approaches to estimate the private returns on schooling as the excess benefits over the costs. Mincer's approach (1974) was widely used in economic literature explaining the percentage change in income as a function of schooling and experience.

Economists indicated education's endogeneity problem in the wage function. This endogeneity could be a result of omitted variable bias or measurement error in estimating the education covariate. These problems lead to distortion of the ordinary least squares (OLS) estimate without specifying which one prevails. The main source of omitted variable bias is the potential correlation between the schooling coefficient and innate ability. The researchers have no consensus about the right controls for ability or motivation and the data on these vectors are typically unavailable. To overcome the omitted variable problem, economists employ three approaches to finessing it in the wage and education functions. The first one is trying to control for ability signaling and investigate whether schooling still has a strong impact on earnings. Thus, any difference could be attributed to the signaling effect of education. For example, in self-employment, education has no value as a signal in determining wages, since individuals know their own productivity (Spence 1978). The main problem with the self-employed distinction is that self-employment is not random, as individuals with specific characteristics (usually unobservable) often choose to be self-employed. The second approach is distinguishing between ability and productivity by directly including ability measures (Dearden 1999). The 
main concern here is that the ability measures need to indicate ability to make money rather than ability in an IQ sense. The third approach is the instrumental variable (IV) approach, which solves the omitted variables problem by using variations in the schooling coefficient due to either natural or randomized experiments. The possible source of instruments coming from a natural experiment ${ }^{1}$ could be from differences in the cost of education due to residing in a place close to a higher educational institution (Card 1994) or regional and temporal variation in school construction (Duflo 2001). Other researchers used the change in school-leaving age (Harmon and Walker 1995; Meghir and Palme 1999) or quarter of birth interacted with a year of birth (Angrist and Keueger 1991) to instrument the educational attainment. In most cases, the IV estimates are greater than OLS. Most of the literature interpreted this difference by the compiler effect, since IV estimates represent the rate of return for the subgroup most affected by the treatment/instrument (local average treatment effects). In this case, the intervention affects a subgroup with a relatively high marginal return to schooling. Another possible reason for larger IV than OLS estimates are the measurement error in estimating the schooling coefficient (Krueger and Ashenfelter 1992; Dearden, Reed, and Van Reenen 2006). In addition to the endogeneity, the OLS estimation of the effect of schooling on earnings might suffer from selfselection bias. Economists deal with this issue by using use standard "two-step" estimation method, as proposed by Heckman (1979), which attempts to control for the selection by modeling what determines it. $^{2}$

This section provides an overview for the returns to schooling in Palestine by discussing several studies conducted for different periods of time, highlighting the main findings of each study and its impact during that period. The overall results demonstrate that the returns to education increase exponentially with more educational attainment. There are incentives to supporting

\footnotetext{
${ }^{1}$ Examples of IV in randomized experiments are found in Bloom et al. (1997) and Schochet and Burghardt (2008). These studies used the random-assignment admission to a training program to investigate the effect of participation in a job training program on earnings.

${ }^{2}$ The Heckman two-step estimation procedure is used to estimate the probit selection equation and the wage equation with the inverse Mills ratio (denotes the standard normal density function, and is the standard normal cumulative distribution function).
} 
female higher education and guaranteeing them equal employment opportunity to increase their participation in the workforce. There is a gender gap in returns in favor of females, and their marginal returns to education are higher than for males. Investment in education will eventually provide the labor market with educated people, which significantly contributes to reducing unemployment and increasing wages. Also, it will reduce the dependence on employment in Israeli, which has two negative consequences on the Palestinian labor market. First, wages in the domestic labor market are negatively affected during closure periods due to increased domestic labor supply. Second, workers with low educational attainment earn better wages in Israel than the educated labor employed locally, which leads to reducing the economic returns to schooling.

People living in the occupied Palestinian territories are facing different challenges affecting their choice to invest in education. First, investment in human capital is less risky than physical capital, since it is less likely to be confiscated or demolished by the Israeli Authority. Second, working inside Israeli markets provides better wages and requires little or no educational attainment compared to local markets. Third, there has been a remarkable increase in the unemployment rate among university graduates in recent decades (Alkafri 2011). Finally, the private returns to education in Palestine are still less than those found in other countries. ${ }^{3}$

Since the 1967 war to today, the Palestinian economy has experienced different challenges affecting the labor market. The consequences of these events on the returns to human capital were different. The first was increasing the supply of educated labor due to an increase in university and community college graduates after 1980 (Angrist 1995). Then the First Palestinian uprising (Intifada) started in late 1987 and lasted until 1993. During that period, the Israeli Authority imposed restrictions on labor movements, which led to a reduction in the supply of Palestinian workers to Israeli markets. Also, that period was characterized by the loss of many school days and an increase in school dropouts. The First Intifada ended with the signing of the

\footnotetext{
${ }^{3}$ Average returns to schooling from the OLS are around 6 percent internationally but over 9 percent from these alternative methods. The UK experiences a higher return on investment in human capital; the comparison is between 7 percent and 9 percent from the OLS to a range of 11 percent to 15 percent from the IV/experimental methods (Harmon, Oosterbeek, and Walker 2000).
} 
Oslo Accord in 1993. As a result of this agreement, the Palestinian Authority was established with partial administrative and security controls on certain areas in the Palestinian territories, which increased the demand for educated labor. In 2000, the Second Intifada started and lasted until 2005. During the period, the Israeli government imposed a closure on the West Bank and Gaza Strip and then substituted Palestinian laborers with foreign workers, which resulted in a remarkable negative effect on Palestinian wages with a sharp increase in unemployment. During the Second Palestinian Intifada, the Israeli Authority built the separation wall around the West Bank, which imposed severe restrictions on Palestinian movement. Finally, since 2006, the Palestinian National Authority (PNA) has experienced a reduction in the volume of the financial aid, which represents the vast majority of the Palestinian budget; in particular, a relatively high proportion of aid is given to the PNA based on political considerations rather than development matters (Sarsour, Naser, and Atallah 2011). This reduction also has negative consequences for nongovernmental organizations ( $\mathrm{NGOs)}$, as most of these organizations receive their funding from Western countries and employ a remarkable portion of university graduates to work on their projects.

Angrist (1995) employed the quarterly Territories Labor Force surveys conducted by the Israeli Central Bureau of Statistics (CBS) for men aged 18-64 years, interviewed in the years 1981-91. He controlled for other covariates that may affect wages in addition to educational attainment, potential experience, and potential quadratic experiences, such as place of residence (Gaza versus the West Bank), refugee camp or urban residence, employment in Israel, year of interview, and interview quarter effect. Moreover, he controlled for individual heterogeneity by adding the field of specialization for university graduates and job classification codes. His main results suggested that the sharp decrease in the private returns to schooling since 1981 is due to an increased supply of university graduates, even after allowing for individual heterogeneity. This continuous sharp decrease reaches almost zero premiums for the group with 13-15 years of schooling in 1988. The trend is similar for the group with 16 or more years of schooling. In addition to the supply shift, the political factor might explain the decline in schooling differentials in the labor market, such as reducing the flow of financial resources from Arab 
countries. For example, Jordanian-funded public sectors, such as schools in the Palestinian territories, experienced dramatically slow economic growth after 1983. The reduction in employment opportunities for Palestinians in Arab Gulf countries after 1982 led to declining remittances to the Palestinian territories. Finally, the disruption in local economic activity during the First Intifada contributed to the continuous decrease in wages for educated workers.

To correct for possible measurement error in school attainment, Angrist (1995) used schooling levels reported in the previous interview as the IV in the equation for the subsequent interview. The results for IV estimates are virtually identical to the OLS estimates.

However, the Angrist (1995) study had some limitations that can produce a potential source of bias. The labor market in the occupied Palestinian territories during the sample period (1981-91) lacked an effective private capital market or financial institutions with the power to extend loans to Palestinians, which contributed to a decline in returns to schooling. Moreover, this study excluded women, who experienced an increase in their educational attainment during the sample period and who were usually employed in Palestine. Finally, data on wages are often poor even in the best circumstances: take into consideration that part of the employment data was collected by employees of the Israeli civil administration during the civil disturbances of the First Palestinian Intifada. These data may be less accurate than data from comparable labor force surveys conducted elsewhere.

Angrist (1998) provides a follow-up study and attempts to answer whether the returns to schooling had recovered in the period 1992-95. During that period, the PNA was established with administrative authority over certain areas. The schooling coefficients began to increase significantly for residents of the Gaza Strip, while the return to the group with $16+$ years of schooling substantially increased in 1995 for residents of the West Bank; he explained this was a result of an inflow of investment and the increase in civil and administrative jobs generated by the PNA's establishment. Finally, he recommended that the Palestinian leaders consider efforts directed toward reducing the imbalance in returns to human capital between Gaza and the West 
Bank, either by changing the geographic distribution of public sector employment or by making investment in the West Bank more attractive.

As Angrist (1995, 1996, 1998) notes, consecutive studies about the Palestinian labor market focus on male subjects only. Daoud (2005) sheds light on the gender gap in returns to schooling, comparing the outcomes in two different years (1999 and 2001). The major event between those two years was the outbreak of the Second Intifada in September 2000, which negatively affected male and female wages through the creation of chokes in demand for and supply of Palestinian labor. First, the continuous closures reduced Palestinian workers' ability to find jobs in the Israeli market and led to an increase in the labor supply in the domestic market. Second, the motivation for some women to find a job was increased to compensate for the overall loss in household income due to the breadwinner's job loss. Third, the continued cycle of violence forced many Palestinian workers to take up residence in the locality of their workplace, which is a more difficult option for women than it is for men. Finally, many organizations either reduced employment or their workers' wages as a result of a general economic depression in the Palestinian territories.

Compared to Angrist's (1995) sample, the average years of schooling in the Daoud (2005) study for males increased from 8.65 percent (for the period 1981-99) to 9.3 percent and 9.47 percent in 1999 and 2001, respectively, while female's education lasted 15 percent to 16 percent less than male's ( 7.68 years and 7.93 years in 1999 and 2001, respectively). Other notable aspects in Daoud's (2005) sample are that the average female wages are 24 percent to 25 percent less than male wages and individuals with higher levels of schooling are less likely to be employed in Israel. Finally, men's education does not affect their wages when they are employed in the Israeli market. The overall results of the study show that the returns to schooling in Palestine during 1999 and 2001 are lower than what is reported in the literature for many countries. An additional year of schooling is associated with 2.57 percent to 2.75 percent increase in average wages. But these outcomes are a little higher than those obtained by Angrist (1995) for the year 1991 (1.7 percent). In contrast to Angrist's 1998 results about shrinking the gap between refugees and 
nonrefugees wages, Daoud (2005) finds refugees earn 3-4 percent less than nonrefugees. Consistent with Angrist (1995, 1996, 1998), the relative wage of Palestinian workers employed in Israel and the settlements is greater than that for all schooling categories. With regard to the gender gap in returns to schooling, females with $16+$ years of schooling experienced more private returns to schooling than males, with the same educational attainment level either before or after the Second Intifada. However, schooling for both genders dramatically decreased in 2001, but it was still higher for females than it for males (23.7 percent and 20.3 percent for males in 1999 and 2001, respectively versus 39.9 percent and 23 percent for females). Daoud (2005) finds that during the Second Intifada, wages fell on average, but more so for unskilled male workers. However, the wages of females with 0-12 years of schooling were not as adversely influenced by Israeli closures. Since the OLS may suffer from self-selection biases, Daoud (2005) used both the household head's education and family size as IVs. Also, he used Heckman's (1979) two-step procedures to correct for self-selection bias for the set of variablessuch as family size, household total wage income, marital status (divorced or widowed), and place of residence - that affect a woman's decision to work.

Tansel and Daoud (2011) compared the returns to education between Turkey and Palestine in 2004 and 2008, using the former country as a benchmark. Turkey has a much more stable economy than Palestine, with an open border and access to other international markets. Females' participation in the Turkish labor force is higher than in Palestine, and the capacity of the private sector in Turkey is much stronger as well. As a consequence, Turkey economy was more affected by the 2008 global financial crisis than Palestine, since the former is more integrated into world economy while the latter is more dependent on foreign aid. This study used Mincer's equation to estimate the private returns to human capital; then the authors adjusted the biases that may arise due to self-selection using Heckman's (1979) two-step procedure. The main results suggest that the returns to an additional year of schooling are lower in Palestine than in Turkey: in 2004 and 2008, they are 5.4 percent and 4.1 percent versus 11.7 percent and 11.8 percent in Palestine and Turkey, respectively. In both countries, the returns to education for females are larger than those for males. The gender gap tends to be larger in Palestine than Turkey; one 
explanation for this is attributed to low labor market participation for females coupled with many opportunities for women in NGOs and international organizations. Another advantage of this study is that it compared the returns to education for different education level in both countries. Regarding this, the study reported that the returns to education have declined from 2004 to 2008 at all levels except the high school level in Palestine. Also, the public sector reported the highest returns to human capital compared to other sectors, such as the private formal and informal sectors, as well as NGOs and international organizations. The reason could be due to the fact that public sector wages are determined administratively by the level of education and tenure rather than productivity.

Daoud and Shanti (2016) investigated the gender gap in returns to education based on employment sector using survey data for the years 1999, 2001, 2007, and 2010. Consistent with other studies, they found that females' returns to education are higher than males' for almost all level of education. Gender differences do exist by sector and within each sector. Overall, the gender wage differential shows higher predicted log hourly wages for females than for males for all years in the public sector. Their results are explained by the lower educational levels found in the private sector than in the other sectors (governmental or NGOs).

Rizk (2016) employed the Harmonized Household Income and Expenditures Survey collected in 2010-11 in Arab countries to compare the returns to education in Palestine and three other Arab countries (Egypt, Tunis, and Sudan). Rizk (2006) used Mincer's (1974) method of providing further analysis according to educational level and occupation group. Her main results are consistent with previous studies that demonstrate the gender gap in returns to schooling to the favor of females. For both sexes, and after adjusting the results for job categories and region, she found that an additional year of schooling is associated with a 4.6 percent increase in daily wages. In general, the returns to education in Palestine are better than in Sudan and Egypt (4.4 percent and 2.2 percent, respectively), but less than the estimated coefficient in Tunis (6.6 percent). Rizk (2006) attributed the overall decline in returns to education in these Arab 
countries compared to other countries as a mismatch between educational system outcomes and the labor market's needs as a consequence of the free educational system.

Despite this, the economic returns to school are greater for females than males in Palestine; the Palestinian labor market is characterized by a low female participation rate. Alkafri (2011) attributes the significant gender employment gap in Palestine to the positive relation between the increasing female unemployment rate and their educational attainment. This unemployment gap will increase if it is accompanied by some social norms of restriction on female movement and when the supply of female graduates in some academic disciplines (in particular, the humanities) exceeds the demand for them in the labor market. The persistence of this phenomenon makes households reluctant to invest in their daughter's education.

Fallah et al. (2020) provides empirical evidence that the decline in labor demand for educated females contributes to their low participation in labor force. This continuous decline of female labor force participation is accompanied by the expansion of their educational attainment in recent years.

\section{THE ECONOMIC COSTS OF THE ISRAELI-PALESTINIAN CONFLICT}

\subsection{Political Violence and the Economic Conditions}

There is a strand of literature that has attempted to investigate the relationship between economic conditions and engagement in violent political conflict. Economists assume that the opportunity cost of involvement in violence is lower for those individuals who suffer from poor economic conditions, such as low income and high unemployment, than other individuals who live in a stable environment (Freytag et al. 2011; Krueger and Laitin 2008). On the other hand, some other economists find the opposite. For example, Krueger and Malečková (2003) examined the relationship between political violence and poverty by using data from several countries, finding that it is not the poor and uneducated that primarily support terrorism. Economic status, 
especially educational attainment, is either positively or not related to supporting or engaging in political violence. Berrebi (2007) found similar results, noting that Palestinians engaged in suicide bombings had a higher level of education and lived under better economic conditions than other Palestinians.

Sayre (2009) used data on Palestinian suicide attacks against Israeli society during 1993-2001 to assess the degree to which economic and political conditions in the West Bank and Gaza Strip affect the frequency of the attacks. Sayre (2009) employed OLS estimation with a fixed-effects negative binomial model to account for unobserved heterogeneity between time period and district characteristics. The main results indicated that poor labor market conditions are correlated with increases in a suicide bombing, but that the specific political event was also important. Saleh (2009) found the same conclusion: improving Palestinian economic condition (higher wages, less unemployment) will reduce the incentive for Palestinians to engage in political violence against Israel. He also alluded to the nonmonotonic statistical link between economic conditions (unemployment and wages) and violence, suggesting that improving living conditions and increasing employment opportunities for Palestinians will not lead to elimination of attacks against Israelis - it will only reduce them.

Miaari, Zussman, and Zussman (2014) explored the causal relationship between Israeli restrictions on Palestinian movement and involvement in political violence. The identification strategy relied on a quasinatural experiment by using the variations in the pre- and post-Second Intifada employment rates in Israel across Palestinian localities, including the number of Palestinian fatalities in each locality as a proxy for involvement in the conflict. They found that Palestinian localities in the West Bank that suffered from severe unemployment due to the Israeli restrictions on Palestinian movement after the Second Intifada erupted in the second half of 2000 were more heavily involved in the Israeli-Palestinian conflict. In other words, during that period (2000-5), any Israeli policy aimed at reducing Palestinian unemployment inside Israel would eventually lead to a rise in the number of Palestinian fatalities. 
Cali and Miaari (2015) shed light on the relationship between the exogenous economic variables and involvement in the violent conflict. Their results indicated that the improved employment opportunities resulting from increasing trade (in particular, exports) during the late 1990s, reduced the population's incentives to engage in political violence during the Second intifada, measured per number of fatalities caused by Israeli per locality. ${ }^{4}$

Benmelech, Berrebi, and Klor (2010) provide evidence of the adverse economic consequences of Palestinian suicide attacks (2000-6) inside Israel in the attacker's district of origin. During the Second Intifada, a successful attack against Israel led to increased unemployment by 5.3 percent in an average Palestinian district (relative to the average unemployment rate); it also lowered the average wage by 20 percent in the offending district. Moreover, a successful attack caused a reduction in the number of Palestinians working in the Israel labor market in the two quarters following the attack. ${ }^{5}$

\subsection{The Economic Costs of the Israeli-Palestinian Conflict on the Labor Market}

Palestinian employment inside Israel started after the 1967 war. Part of Israeli's leadership encouraged the integration between the Palestinian and Israeli economies to improve the quality of life for the Palestinian people. They argued that higher income and lower unemployment would reduce Palestinian resistance to the occupation. However, providing Palestinian access to Israeli territories raised some concern regarding security (Gazit 1995). Increasing movement restrictions on Palestinian laborers reduced their ability to access the Israeli market and increased absent days, motivating Israeli employers to substitute them with foreigner workers. A lot of

\footnotetext{
${ }^{4}$ Cali and Miaari's (2015) main estimation suggests that an increase of USD 10 million in Palestinian exports of a sector employing 10 percent of the locality's private employment reduces subsequent conflict-related fatalities in that locality by between 2.1 percent and 2.8 percent.

${ }^{5}$ In all specifications, Benmelech, Berrebi, and Klor (2010) controlled the demographic characteristics accounted for, including average years of education, percentage of population living in a refugee camp, average age, proportion of males in the local population, and proportion of married population. Also, a West Bank dummy was included to control for regional unobservable characteristics that are constant over time, as well as year fixed effects. The error term was clustered at the regional level, capturing nonsystematic determinants of the district's changes in economic conditions. The identification strategy does not focus on levels, but rather changes of all variables used in the analysis, thus effectively controlling for districts' fixed characteristics that may jointly affect economic conditions and the occurrence of suicide attacks.
} 
factors play a significant role in creating barriers for Palestinian movements, such as closures, checkpoints, curfews, having many localities in the West Bank categorized as Area $\mathrm{C}^{6}{ }^{6}$ and the existence of the separation wall after 2005. Following the outbreak of the Second Intifada in September 2000, the number of Palestinians from the West Bank and Gaza Strip employed in Israel dropped sharply. This shock to the labor supply also had a heterogeneous impact on Palestinian wages based on their educational attainment (skilled labor versus unskilled labor) and employment sector (public versus private and rural wages versus urban wages). The following papers empirically discuss the impact of the Israeli-Palestinian conflict on the labor market before and after the Second Palestinian Intifada.

One of the earliest studies discussing the impact of Israeli policies on both the Israeli and Palestinian labor markets was Angrist's 1996 study, which estimated the wage premium for men working in Israel ranges from 25 percent to 35 percent for the period 1988-91 compared to a 0 percent to 18 percent premium during the period $1981-87$. He indicated that wages paid to Palestinians working in Israel are negatively correlated with days worked by Palestinians in Israel (-14 percent for all industries). Angrist used the supply shocks in the Palestinian labor supply as an IV to estimate the effect of Israeli labor market demand for Palestinian workers. Overall, the results implied that the short-run Israeli demand for Palestinian labor is not very elastic. $^{7}$

In his following paper, Angrist (1998) investigated the effect of the repeated sharp restrictions on Palestinian access to Israeli labor markets on the Palestinian labor market in the period 1992-95, which was characterized by increased violent activities on both sides, as well as the establishment of PNA, which created employment opportunities for many Palestinian laborers.

\footnotetext{
${ }^{6}$ Area C consists of approximately 60 percent of the West Bank area where the Palestinian Authority does not have any control there (security or civil). Communities in Area $\mathrm{C}$ are at higher risk of adverse life circumstances due to the lack of primary services (Vishwanath et al. 2014).

7 Angrist (1996) employed administrative data obtained from Israeli Army records on days under a curfew imposed in the Palestinian territories, combined with control variables on civil disturbances as IVs. The following covariates were treated as endogenous variables: days worked in Israel, days worked in the comparison region, wages in the comparison region, and total earning in the comparison region.
} 
He found that the Israeli labor market's dependence on Palestinian labor has been reduced due to the substitution of Palestinian workers with guest workers, also due to the structural changes in the Israeli economy. He indicated that there are a variety of economic and social factors that limit the benefits from migrant labor, such as providing them with a full range of civil rights and social benefits and substitution of capital mobility for labor mobility.

Mansour (2010) attempted to identify the Palestinian labor market's response to an increase in the supply of workers after the Second Intifada separately from the direct effects of the political instability. This distinction could be useful in evaluating border policies that are related to the Palestinian and Israeli nations. He employed quarterly variations in Labor Force Survey data by city for the period 2000-4 to investigate the effect of the labor supply (without and with the distinction between skilled and unskilled labor) on the average wages and unemployment rate of low- and high-skilled workers. The labor supply covariate was instrumented by the log of the number of individuals usually working in Israel from each city. The source of endogeneity for the labor supply could be due to the change in the labor force's size in response to the closure of the borders or because workers drop out of the labor force or emigrate. The main results suggested that an increase in the supply of low- and high-skilled labor had an adverse impact on low-skilled wages, while the wages of high-skilled labor seem to respond mostly to increases in their own labor supply.

Miaari and Sauer (2011) concluded that the impact of substituting Palestinian labor with foreigner workers is relatively stronger than the impact of temporary closures in the Palestinian market. The former tends to be permanent, with a long-run substitution effect. In order to reach the previous conclusion, they estimated the impact of foreigner workers and closure days on either monthly wages or employment status inside Israel after controlling for other individual and residential characteristics (i.e., urban, camp, or rural). The number of foreign workers (the variable of interest) was instrumented by the cumulative number of foreign worker permits issued through each quarter over the period 1999-2004. The researchers employed the IV strategy since they argued that the number of foreign workers can correlate with the error term in 
several aspects. The first one is related to labor demand and other macroeconomic factors in Israel and surrounding region, for example, an increasing number of illegal entries into Israel due to voluntary movement of Palestinian laborers back into the local economy of the West Bank and Gaza Strip. Secondly, the random error may contain unobserved individual attributes that are potentially correlated with the number of incoming foreign workers to Israel. These could be relevant to productivity, motivation, geographical preference to work inside Israel (in the case of no movement restriction), and the ability to communicate in Hebrew.

Cali and Miaari (2018) provided empirical evidence for the effect of mobility restrictions on the West Bank labor market. They employed a combined data set from the Labor Force Survey and Geographic Information System (GIS) data on varies types of physical barriers to movement during the period 2000-9. Their main findings suggested that barriers to mobility have a significant negative impact on the probability of being employed, wages earned, and the number of days worked per month, while the movement restrictions lead to an increase in the number of hours worked per day. These effects are substantially attributed to the checkpoints, while the other barriers have only a weak impact. The findings indicted that the labor market adjusted to several restrictions through lower wages rather than through lower employment. For example, placing one checkpoint one minute away from a locality will significantly reduce its residents' hourly wage by 5.2 percentage points and reduce their probability of being employed by 0.5 percentage points. ${ }^{8}$

\subsection{The Economic Costs of the Israeli-Palestinian Conflict on Human Capital}

Over the last decades, a growing body of literature shed light on the damage to human capital due to conflict exposure. These damages include several short- and long-term outcomes affecting education, child labor, child wellbeing, and health. The following section presents a brief review

\footnotetext{
${ }^{8}$ For example, in 2007, Cali and Miaari (2018) estimated that the effects of reducing employment opportunities and wages were translated into a reduction in the West Bank GDP of around USD 229 million or 6 percent. Most of these losses are due to lower wages.
} 
of some of these studies discussing the effect of the Israeli-Palestinian conflict on human capital accumulation.

The first stream of literature discusses the short- and long-run impact of violence on a child's educational attainment. Most of these studies employ a similar identification strategy based on the plausibly exogenous variation in conflict intensity induced by combining household survey data with a measure of conflict intensity and geographic location of a community during the conflict period.

Al Kafri (2002) used the quarterly labor force household survey data collected in 2000 and 2001 (before and after the start of the Second Palestinian Intifada) to see the impact of the Second Intifada on children's decision to choose schooling, work, or both. He found that the Second Intifada increased the probability of boys going to work and of girls leaving school in an attempt to help their families, especially after the increase in poverty and unemployment created by the conflict. However, this study did not control for a number of significant explanatory variables, such as the market wage, household income, and number of closure days, nor did it suggest a transmission channel that could affect a child's decision to work rather than going to school.

Di Maio and Nandi (2013) showed that from the Second Intifada until the end of 2006, the increasing number of border closure days increased the probability of child labor and reduced school attendance. They considered reductions in local wages, decreases in the household income, and the likelihood that the father was employed in Israel to be different transmission mechanisms through which closure days possibly increased child labor.

Brück, Di Maio, and Miaari (2019) estimated the "reduced form" effect of the exposure to the Israeli-Palestinian conflict during the Second Intifada (2000-6), measured by the number of Palestinian fatalities at the school locality and high school exit exam performance. Using year and school fixed effects to control for unobserved locality and time effects, their results indicated that the increased exposure to the Israeli-Palestinian conflict reduced the probability of passing 
the final exam and securing university admission. The authors suggested changes in the quality of the school-level learning conditions and their adverse effect on student psychological wellbeing as potential transmission mechanisms for explaining their results.

Di Maio and Nisticò (2019) investigated the impact of parental job loss during the Second Palestinian Intifada on their child's school enrollment status. To account for the endogeneity, they employed the variation in the number of fatalities across Palestinians localities as the IV. The results suggested that the household head's job loss increases a child's probability of dropping out of school by 9 percentage points. The effect varied with the gender, school grade, and the child's academic ability, as well as with parental education and the number of children in the household.

Jürges et al. (2020) showed that an increase of household's exposure to conflicts during the Second Intifada (2000-5) had an adverse long-term impact (7 years after ending the second Intifada) on their offspring's school achievements measured by the child's school grade point average (GPA) during 2012-13 academic year. Similar to Di Maio and Nisticò (2019), Jürges et al. (2020) used the same IV (locality-level variation in the conflict intensity measured by number of fatalities across locality) to account for the endogeneity. Also, they proposed noncognitive skills — such as the "big five" personality traits and the "internalizing" and the "externalizing"10 behavioral problem resulted from Strengths and Difficulties Questionnaire (SDQ) ${ }^{11}$ —as a channel of exposure in children's educational attainment.

\footnotetext{
${ }^{9}$ The "big five" traits covers the following characteristics: openness, conscientiousness, extraversion, agreeableness, and neuroticism. These are widely used to gauge psychological well-being of children; see Barlett and Anderson (2012)

${ }^{10}$ Psychologists differentiate between two types of children's behaviors and disorders based on their reactions to stressors. The externalizing behavior includes symptoms of aggression and delinquency, while the internalizing problems measures symptoms of depression, anxiety, somatic complaints, and social withdrawal (Foster, Garber, and Durlak 2008).

${ }^{11}$ The Strengths and Difficulties Questionnaire (SDQ) is a brief behavioral screening questionnaire about 3-to-16year olds. There are currently three self-reported versions of the SDQ in the following categories: children, parents, and teachers. For a detailed description of the SDQ, see http://www.sdqinfo.com/.
} 
Saad and Fallah (2020) use the closure of the Israeli labor market during the Second Intifada (2000-5) to investigate the impact of a large labor market shock on the educational choices of Palestinian youth. This study employs difference in difference methodology by using the variation in the geographical distribution of commuters within the West Bank prior to the Second Intifada to compare high school dropout rates between localities with different shares of Palestinians workers who commuted to Israel before and after the Second Intifada. The results show that the closure led to a significant decline in high school dropout rates in the case of male students aged 15-19 years, but not for female students. Additionally, the findings suggest that the localities with high commuting shares experienced a decreasing gender gap in high school dropout rates compared to other localities with low commuting shares.

The second stream of literature that discusses the Palestinian-Israeli case sheds light on the cycle of violence by employing the number of fatalities on both sides. Jaeger and Paserman (2008) investigated the short-run dynamics of Israeli-Palestinian violence during the Second Intifada. Using the number of fatalities from each side as a measurement of the violence's intensity, they found that Israel reacted predictably and systematically to Palestinian violence, while Israeli violence did not lead to an increase in Palestinian violence. In their second paper (Jaeger and Paserman 2009), they indicated that the Israeli's targeted killing of Palestinian leaders led to increased violence by the Palestinians, but it did not lead to higher levels of Israeli fatalities. Jaeger et al. (2012) suggested that, in the short run, the violence from Israel reduced Palestinian support for the moderate political party and the peace process, though this effect diminishes within three months. However, Palestinian violence plays a small role in formulating the Palestinian public opinion, except between the radical factions, but it does not induce a shift between supporting the moderate and radical factions. 


\section{WAGE DIFFERENTIAL IN THE PALESTINIAN LABOR MARKET}

\section{1. The Effect of Area C, Rural, and Nonrural Areas and Refugees Status on Wages}

As a consequence of the Oslo Peace Accord (1993), the PNA was established to provide a different level of control over the West Bank and Gaza Strip territories. The PNA has control over both security and administration (e.g., health, education, taxation, etc.) in Area A. Their control in Area B is limited to civil administration only, with no control in Area C. The latter is mostly rural and represents approximately 60 percent of the West Bank territory. Communities in Area $\mathrm{C}$ are living in difficult life circumstances due to the lack of major services (UNSCO 2014), though Area $\mathrm{C}$ is key to future Palestinian economic development. There are many direct and indirect economic benefits of eliminating the restrictions on movement and investment in Area $\mathrm{C}$ (Vishwanath et al. 2014), including improvements in agriculture, mineral and stone mining, quarrying, tourism, and telecommunication. The expected growth that could be generated through the lifting of restrictions on Area $\mathrm{C}$ would increase the potential Palestinian value-added by USD 3.4 billion. The indirect benefits would be reflected as an improvement in the quality of life there since the vast majority of Palestinian economic activities are to some extent dependent on the quality of transportation, electricity, water, and telecommunications infrastructure. Additionally, the expected substantial increase in GDP would lead to creating many employment opportunities in the West Bank (Niksic, Eddin, and Cali 2014).

Fallah and Daoud (2015) investigated the impact of restrictions in Area C on wages of Area C workers. They employed an individual-level survey, collected on a quarterly basis by the Palestinian Central Bureau of Statistics (PCBS) during the period 2001-8. They restricted their sample only to those who worked in Palestinian territories (Areas A, B, and C), excluding those who worked in Israel to avoid an estimation bias that could mask an urban-rural wage differential. The estimation was based on the OLS technique, controlling for other demographic- 
and locality-level variables. The standard error was clustered at locality level. ${ }^{12}$ To deal with the workers' unobserved characteristics (such as innate abilities), the researchers relied on the Oaxaca-Blinder (1973) ${ }^{13}$ decomposition technique, which allowed them to identify the unexplained part (residual) of the wage differential. Their results suggested that Area $\mathrm{C}$ workers suffer from a wage penalty ${ }^{14}$ compared to workers in Areas A and B. Moreover, by comparing average wages of Area $\mathrm{C}$ workers with other rural workers, they concluded that the wage difference is statistically insignificant, which indicated that the observed wage penalty for Area $\mathrm{C}$ workers could be attributed primarily to a rural environment effect rather than to Israeli economic restrictions that take place there. The reduction in the average wages due to the shock in labor demand in Area $\mathrm{C}$ was subsequently raised due to the shocks in the labor supply. The latter (commuting-labor supply) was proposed as a potential transmission mechanism since the residents in Area $\mathrm{C}$ are more likely to commute than their peers in other rural areas.

With regards to the differential wages between rural and nonrural areas, Daoud and Fallah (2014) used quarterly survey data for the period 1999-2012 and showed that employment in agriculture reduced the wages for both rural and nonrural workers. Also, consistent with other previous studies, they indicated that the Israeli labor market provides a wage premium of 60 percent to 70 percent for nonrural workers and 40 percent to 50 percent for rural workers compared to the local market. In addition to using the standard OLS estimation, they adjusted the unpaid wage selectivity bias (for those who are employed in agriculture) by controlling for parents' type of industry. In particular, whether workers' and their parents' type of industry is the

\footnotetext{
${ }^{12}$ One potential problem of main OLS estimation is that its residuals might be spatially correlated, biasing the standard error of the estimates downward. Therefore, the standard was clustered at the locality level, assuming that the error terms are correlated within geographic clusters but uncollected across them.

${ }^{13}$ The decomposition technique consists of separating the wage equation for those working in Area $\mathrm{C}$ and other wages in Areas A and B. These separations then consist three elements: 1) the wage differences related to the endowment effect capture the explained part of the model and are attributed to differences in workers' characteristics; 2) the wage differential that is attributed to the difference in the estimated coefficient; and 3) the interaction between the endowment and coefficient effects. The second and third terms together constitute the unexplained part (residual) of the wage differential.

${ }^{14}$ The main estimation shows lower wages for Area $\mathrm{C}$ workers by about 8 percent relative to workers in Areas A and B. This penalty reduces to approximately half after controlling for workers' demographic characteristics and locality variables, but is still significant.
} 
same. Also, he employed Heckman's (1979) two-stage estimation to correct the industry selfselection bias. The main results show that the coefficient for the agriculture industry lower wages for workers in this sector by 34 percent to 37 percent for nonrural and rural areas, respectively.

Hallaq (2019) indicated the existence of a wage differential in the Palestinian labor market based on refuges status. This wage gap has an opposite direction in the West Bank and Gaza Strip. In the West Bank, Palestinian nonrefugees enjoy a wage premium and the wage gap has more influence on low-skilled workers and those in the private sector. In Gaza, the wage gap favored refugee workers and has more substantial impact among unskilled workers.

\subsection{Employment Sector and Wage Differentials}

Public employment accounts for 21.6 percent of total employment in Palestine. This percentage varies significantly between the West Bank and Gaza Strip (PCBS 2016). ${ }^{15}$ Salaries represent the vast majority of the PNA's overall budget. ${ }^{16}$ Unlike other countries, where taxes are the major source of financing public salaries, the PNA relies heavily on international aid to finance its expenditures (Sarsour, Naser, and Atallah 2011). This section presents wages differentials between the public and private sectors and the public sector's impact on private employment.

Miaari (2009) utilized the PLFS conducted between 1998 and 2006 to measure the wage differential between public and private employment in the West Bank and Gaza Strip. The wage differential was decomposed into the human capital effect and an unexplained effect using Oaxaca-Blinder techniques. The results suggested that before the Second Intifada period, the public sector experienced wage penalties, but this penalty disappeared and then reversed over time. There was a wage differential during the post-Second Intifada period in favor of the public sector due to the high demand for employment in public sector. At the same time, there was an increase in the Palestinian labor supply due to the sharp decrease in the number of Palestinians

\footnotetext{
${ }^{15}$ Public employment represents 36.4 percent and 15.4 percent of total employment in the Gaza Strip and in the West Bank, respectively (PCBS 2016).

${ }^{16}$ Salaries represent 55 percent of total governmental expenditures (PMOF 2016).
} 
working in the Israeli labor market competing with the low demand for employees in the local private sector. All these factors led to a rapid decrease in private sector wages. Moreover, the wage gap was attributed to the returns to skills composition in the public sector (unexplained effect) rather than a change in the skills composition of public sector workers (human capital effect).

Fallah (2017) explained how the local labor market responded to the changes in public employment in an aid-based economy. Expanding public employment was vital to limiting the negative demand shocks during Second Intifada. The OLS estimation demonstrated that, in the short run, increasing public employment by 100 jobs increases private employment by 71 jobs. The endogeneity led to biasing the OLS estimation since the PNA utilizes public jobs to curb rising local unemployment and as a response to population change. Fallah (2017) employed a district's share of public employment to redistribute the overall increases in public employment across districts. ${ }^{17}$ The findings showed that public employment has a positive impact on both the tradable and nontradable sectors, but favoring the latter. Fallah (2017) proposed three mechanism channels to explain his main result. First, the expansion of public employment has a positive effect on the number of local entrepreneurs (employers and self-employed). Second, the expansion of public employment has no significant negative impact on private wages; since the PNA has to absorb the excess labor supply, it neutralizes the effect of the public wage premium on private wages. ${ }^{18}$ The empirical findings demonstrated that a district's change in private employment is independent of changes in public wages. Finally, the paper indicated the minor role of the tax effect on the private sector. Unlike other countries where increasing taxes to create additional public jobs may decrease labor demand in private employment, the vast majority of public salaries in the West Bank are funded by international grants.

\footnotetext{
${ }^{17}$ The IV estimates results are consistent with the OLS estimation, though the magnitude of the effect is smaller (52 jobs rather than 71).

${ }^{18}$ Algan, Cahuc, and Zylberberg (2002) suggests that the higher public wages would increase returns to seeking public employment, attracting workers out of the private sector.
} 


\section{REFERENCES}

Algan, Y., P. Cahuc, and A. Zylberberg. 2002. "Public employment and labor market performance." Revue économique 53(3): 589-98.

Al Kafri, S. 2002. "Impact of Israeli measures on Palestinian child labor and schooling." Economic Research Forum Working Papers No. 0215. Cairo: Economic Research Forum.

- 2011. "Transition from High Education to the Labour Market: Unemployment within Graduates from the Gender Perspective in the Palestinian Territory." Almalaurea Working Paper No 30. Bologna: Almalaurea.

Angrist, J. D. 1995. "The economic returns to schooling in the West Bank and Gaza Strip." The American Economic Review 85(5): 1065-87.

_. 1996. "Short-run demand for Palestinian labor." Journal of Labor Economics 14(3): $425-53$.

—. 1998. "The Palestinian labor market between the Gulf War and Autonomy." MIT Working Paper 98-5. Cambridge, MA: MIT Department of Economics.

Angrist, J. D., and A. B. Keueger. 1991. "Does compulsory school attendance affect schooling and earnings?" The Quarterly Journal of Economics 106(4): 979-1014.

Barlett, C. P., and C. A. Anderson. 2012. "Direct and Indirect Relations between the Big 5 Personality Traits and Aggressive and Violent Behavior." Personality and Individual Differences 52 (8): 870-75.

Becker, G. S. 1964. Human Capital: A Theoretical and Empirical Analysis, With Special Reference to Education. Chicago: University of Chicago Press.

Benmelech, E., C. Berrebi, and E. F. Klor. 2010. "The Economic Cost of Harboring Terrorism." Journal of Conflict Resolution 54(2): 331-53.

Berrebi, C. 2007. "Evidence about the link between education, poverty and terrorism among Palestinians." Peace Economics, Peace Science and Public Policy 13(1) :18-53.

Bloom, H. S., L. L. Orr, S. H. Bell, G. Cave, F. Doolittle, W. Lin, and J. M. Bos. 1997. "The benefits and costs of JTPA Title II-A programs: Key findings from the National Job Training Partnership Act study.” Journal of Human Resources 32(3): 549-76.

Brück, T., M. Di Maio, and S. H. Miaari. 2019. "Learning the hard way: The effect of violent conflict on student academic achievement." Journal of the European Economic Association 17(5): 1502-37. 
Calì, M., and S. H. Miaari. 2015. "Trade, employment and conflict: Evidence from the Second Intifada." Households in Conflict Network Working Paper No. 186. Berlin: Households in Conflict Network.

- 2018. "The labor market impact of mobility restrictions: Evidence from the West Bank." Labour Economics 51: 136-151.

Card, D. 1994. "Earnings, schooling, and ability revisited." NBER Working Paper No. 4832. Cambridge, MA: National Bureau of Economics Research.

Daoud, Y. 2005. "Gender gap in returns to schooling in Palestine." Economics of Education Review 24(6): 633-49.

Daoud, Y., and B. Fallah. 2014. "Rural Wage Employment: Is There a Premium for Agriculture?" Economic Research Forum Working Paper No. 837. Cairo: Economic Research Forum.

Daoud, Y., and R. Shanti. 2016. "Private-public sector employment choice and wage differentials in Palestine: A gender perspective.” In N. Chamlou and M. Karshenas (eds.), Women, work and welfare in the Middle East and North Africa: The role of sociodemographics, entrepreneurship and public policies. London and Paris: IC Publishing.

Dearden, L. 1998. “Ability, families, education and earnings in Britain.” IFS Working Paper No. W98/14. London: Institute for Fiscal Studies.

1999. "Qualifications and Earnings in Britain: How Reliable Are Conventional OLS Estimates of the Returns to Education?" IFS Working Paper No. W99/07. London: Institute for Fiscal Studies.

Dearden, L., H. Reed, and J. Van Reenen. 2006. "The Impact of Training on Productivity and Wages: Evidence from British Panel Data." Oxford Bulletin of Economics and Statistics 68 (4): $397-421$.

Di Maio, M., and T. K. Nandi. 2013. "The Effect of the Israeli--Palestinian Conflict on Child Labor and School Attendance in the West Bank." Journal of Development Economics 100(1): 107-16.

Di Maio, M., and R. Nisticò. 2019. "The Effect of Parental Job Loss on Child School Dropout: Evidence from the Occupied Palestinian Territories." Journal of Development Economics 141: 102375.

Duflo, E. 2001. "Schooling and Labor Market Consequences of School Construction in Indonesia: Evidence from an Unusual Policy Experiment." American Economic Review 91(4): 795-813. 
Fallah, B. 2017. "The Effect of Public Sector on Private Jobs: Evidence from the Occupied West Bank." Economic Research Forum Working Paper No. 1119. Cairo: Economic Research Forum.

Fallah, B., and Y. Daoud. 2015. "Wage differentials and economic restrictions: Evidence from the occupied Palestinian territories." Economics of Peace and Security Journal 10(1): 1322.

Fallah, B., M. Bergolo, I. Saadeh, A. A. Hashhash, and M. Hattawy. 2020. "The Effect of Labour-Demand Shocks on Women's Participation in the Labor Force: Evidence from Palestine." The Journal of Development Studies (online), August 31.

Foster, C. J. E., J. Garber, and J. A. Durlak. 2008. "Current and Past Maternal Depression, Maternal Interaction Behaviors, and Children's Externalizing and Internalizing Symptoms." Journal of Abnormal Child Psychology 36(4): 527-37.

Freytag, A., J. J. Krüger, D. Meierrieks, and F. Schneider. 2011. "The Origins of Terrorism: Cross-Country Estimates of Socio-Economic Determinants of Terrorism.” European Journal of Political Economy 27: S5-S16

Gazit, S. 1995. The Carrot and the Stick: Israel's Policy in Judea and Samaria, 1967-1968. Washington, DC: B'nai B'rith Books.

Hallaq, S. 2019. "Wage Differential between Palestinian Non-Refugees and Palestinian Refugees in the West Bank and Gaza.” Levy Economics Institute Working Papers No. 941.

Annandale-on-Hudson, NY: Levy Economics Institute of Bard College.

Harmon, C., and I. Walker. 1995. "Estimates of the Economic Return to Schooling for the United Kingdom.” The American Economic Review 85(5): 1278-86.

Harmon, C., H. Oosterbeek, and I. Walker. 2000. The Returns to Education: A Review of Evidence, Issues and Deficiencies in the Literature. London: Centre for the Economics of Education, London School of Economics and Political Science.

Heckman, J. J. 1979. "Sample Selection Bias as a Specification Error.” Econometrica: Journal of the Econometric Society 47(1): 153-61.

Jaeger, D. A., and M. D. Paserman. 2008. “The Cycle of Violence? An Empirical Analysis of Fatalities in the Palestinian-Israeli Conflict." American Economic Review 98(4): 15911604.

Targeted Killings." Quarterly Journal of Political Science 4 (4): 315-42. 
Jaeger, D. A., E. F. Klor, S. H. Miaari, and M. D. Paserman. 2012. "The Struggle for Palestinian Hearts and Minds: Violence and Public Opinion in the Second Intifada." Journal of Public Economics 96 (3-4): 354-68.

Jürges, H., L. Stella, S. Hallaq, and A. Schwarz. 2020. “Cohort at Risk: Long-Term Consequences of Conflict for Child School Achievement.” Journal of Population Economics 1-43.

Krueger, A., and O. Ashenfelter. 1992. "Estimates of the Economic Return to Schooling from a New Sample of Twins." NBER Working Paper No. w4143. Cambridge, MA: National Bureau of Economic Research.

Krueger, A. B., and J. Malečková. 2003. "Education, Poverty and Terrorism: Is There a Causal Connection?" Journal of Economic Perspectives 17(4): 119-44.

Krueger, A. B., and D. D. Laitin. 2008. "Kto Kogo?: A Cross-Country Study of the Origins and Targets of Terrorism." In P. Keefer and N. Loayza (eds.), Terrorism, Economic Development, and Political Openness. Cambridge, UK: Cambridge University Press.

Mansour, H. 2010. "The effects of labor supply shocks on labor market outcomes: Evidence from the Israeli-Palestinian conflict." Labour Economics 17(6): 930-39.

Meghir, C., and M. Palme. 1999. "Assessing the Effect of Schooling on Earnings Using a Social Experiment." Stockholm School of Economics Working Paper No. 313. Stockholm: Stockholm School of Economics.

Miaari, S. H. 2009. "The Public-Private Wage Differential in the West Bank and Gaza: Before and during the Second Intifada.” European University Institute Working Paper, MAX Weber Programme MWP 2009/13. Florence: European University Institute.

Miaari, S. H, and R. M. Sauer. 2011. "The Labor Market Costs of Conflict: Closures, Foreign Workers, and Palestinian Employment and Earnings." Review of Economics of the Household 9(1): 129-48.

Miaari, S., A. Zussman, and N. Zussman. 2014. "Employment Restrictions and Political Violence in the Israeli-Palestinian Conflict." Journal of Economic Behavior \& Organization 101: 24-44.

Mincer, J. 1974. Schooling, Experience, and Earnings. New York: Columbia University Press.

Niksic, O., N. N. Eddin, and M. Cali. 2014. Area C and the Future of the Palestinian Economy. Washington, DC: World Bank. 
Oaxaca, R. 1973. "Male-Female Wage Differentials in Urban Labor Markets." International Economic Review 14 (3): 693-709.

PCBS (Palestinian Central Bureau of Statistics). 2016. "Press Release on the Results of the Labour Force Survey in Palestine.” Technical report. Ramallah: Palestinian Central Bureau of Statistics.

PMOF (Palestinian Ministry of Finance). 2016. “Citizens Budget, 2016.” Technical Report. Ramallah: Palestinian Ministry of Finance.

Rizk, R. 2016. "Returns to education: An updated comparison from Arab countries." Economic Research Forum Working Paper No. 986. Cairo: Economic Research Forum.

Saad, A. F., and B. Fallah. 2020. "How Educational Choices Respond to Large Labor Market Shocks: Evidence from a Natural Experiment.” Labour Economics 66: 101901.

Saleh, B. 2009. "An Econometric Analysis of Palestinian Attacks: An Examination of Deprivation Theory and Choice of Attacks." European Journal of Social Sciences 7(4): 1729.

Sarsour, S., R. Naser, and M. Atallah. 2011. "The Economic And Social Effects Of Foreign Aid In Palestine.” Report. Ramallah: Palestine Monetary Authority, Research and Monetary Policy Department.

Sayre, E. A. 2009. "Labor Market Conditions, Political Events, and Palestinian Suicide Bombings." Peace Economics, Peace Science and Public Policy 15(1): 1-26.

Schochet, P. Z., and J. Burghardt. 2008. "Do Job Corps performance measures track program impacts?" Journal of Policy Analysis and Management: The Journal of the Association for Public Policy Analysis and Management 27(3): 556-76.

Schultz, T. W. 1961. "Investment in Human Capital." The American Economic Review 51(1): 117.

Spence, M. 1978. “Job Market Signaling.” In P. Diamond and M. Rothschild (eds.), Uncertainty in Economics. Amsterdam: Academic Press.

Tansel, A., and Y. Daoud . 2011. "Comparative essay on returns to education in Palestine and Turkey.” IZA Working Paper No. 5907. Bonn, Germany: Institute for the Study of Labor (IZA). 
UNSCO (Office of the United Nations Special Coordinator for the Middle East Peace Process). 2014. "Report to the Ad Hoc Liaison Committee New York." Technical Report, September 22. New York: Office of the United Nations Special Coordinator for the Middle East Peace Process. Available at:

https://unsco.unmissions.org/sites/default/files/un_ahlc_report_sept_2014.pdf

Vishwanath, T., B. Blankespoor, F. Calandra, N. Krishnan, M. Mahadevan, and M. Yoshida. 2014. "Seeing Believes: Poverty in the Palestinian Territories." Technical report. Washington, DC: World Bank Group. 
